\title{
The Adapted Building for the Blind - Case Study
}

\author{
Katarzyna Ujma-Wąsowicz* \\ Silesian University of Technology, Poland \\ Submission: May 14, 2019; Published: May 23, 2019 \\ *Corresponding author: Katarzyna Ujma-Wąsowicz, Silesian University of Technology, Poland
}

\section{Introduction}

In contemporary Poland, disability is no longer a taboo subject. Both in legislative solutions and in public awareness, including through scientific research, many positive things are happening in our country. The author of the account is an architect: a scientist and an academic teacher. For her, the greatest value in acquiring knowledge and in its disseminating lies in, on the one hand, cooperation with foundations working for the benefit of people with disabilities and, on the other hand, activities in associations of professionals who have an impact on the quality of the built environment. (the author is the head of the Silesian branch of Association of Polish Town Planners and is a member of Polish Ergonomics Society).

For people with disabilities, the environment should not only be built without spatial barriers but should also be clear. This legibility understood as the ease with which places can be recognized and organized in a coherent pattern [K. Lynch: Image of the City, 1960], determining free functioning in and outside a building (way finding, navigating, spatial orientation) is very much desired by blind people. Following this message, the author of the study, together with Mariusz Miszuda (a blind leader of the "W Labiryncie" Foundation, based in Katowice/Poland), undertook the task of checking newly built or renovated public facilities for accessibility.

On 25 March 2019, between 3 and 4 p.m., a "research walk" was conducted around the railway station in Gliwice city (Po land), which was renovated about 2 years ago. It has to be objectively admitted that the station seems to be very neat and adapted for people with disabilities (including blind and partially sighted people).

However, visual inspection revealed many ill-considered solutions that make it difficult for blind people to move safely and comfortably around the facility.

These include, among other things:

A. Access to the station: not marked in any way (there are no guides installed in the pavement); the only element helpful in orientation is an audible signal at a pedestrian crossing.
B. Building plan: no map in the building informing about navigation through it, i.e. one that would tell a blind person where there are ticket offices, access to platforms, toilets, shops or waiting rooms.

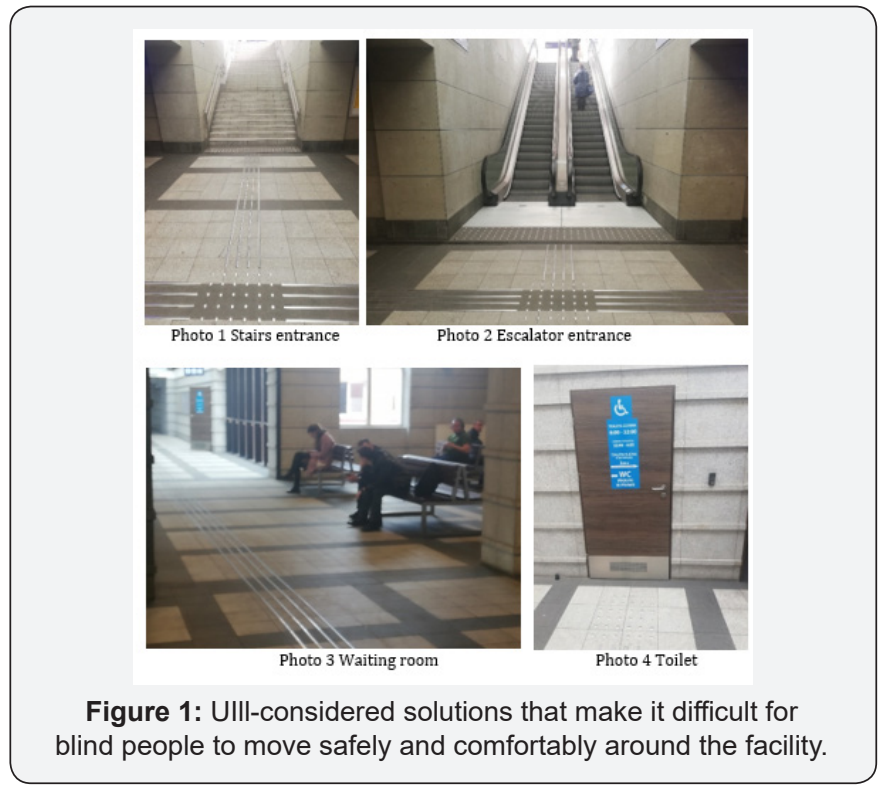

C. Entrance to the platforms: traditional stairs or escalators (the elevator is located in the second corridor of the station). The guides to the stairs are led in their centre (Figure1) (Photo 1 and 2). While there is no danger at ordinary stairs (blind people can cope with such inconvenience on their own), in escalators the guide "between" the stairs poses a real danger. It would be much more convenient to make in both cases, two guidelines to the handrail, which are located at the edge of the staircase.

D. Waiting room: there is no clear information in the floor on where the waiting room is and where a blind person could sit down while waiting for a train (Photo 3).

E. Toilets: independent search for sanitary facilities by a blind person is very difficult - there are no guides to the toilet, there is only visual information on the door (and it should be 


\section{Civil Engineering Research Journal}

written in Braille), the doorbell recalling the staff is moved too far away from the door (Photo 4).

F. There are also other inconveniences.

It is only after reaching the platforms that standard (safe) solutions can be found, which are commonly used throughout Poland.

\section{Conclusion}

The examined object is not functionally complicated. In principle, minor amendments would suffice to make it fully accessible. However, the problem that has been raised lies elsewhere. Many public investments are implemented in Poland, which are carried out in the spirit of universal architecture. However, as these laconic studies show, the lack of understanding by designers, investors and contractors of the functioning of a disabled person (here: a blind person) in the space shaped by them is still a significant issue. It also should be noted why very rarely a convex map is placed in front of the entrance area to objects, which greatly facilitates, but also increases safety in independent movement of a blind and partially sighted person in every building. There is still a lot of work to be done. There is a need not only for social awareness of the needs and limitations of blind people, but also constantly improved knowledge.

Your next submission with Juniper Publishers
will reach you the below assets
- Quality Editorial service
- Swift Peer Review
- Reprints availability
- E-prints Service
- Manuscript Podcast for convenient understanding
- Global attainment for your research
- Manuscript accessibility in different formats
( Pdf, E-pub, Full Text, Audio)
- Unceasing customer service
Track the below URL for one-step submission
https://juniperpublishers.com/online-submission.php

